\title{
Neuronal-derived Nitric Oxide Modulates the Activity of Mouse Detrusor Smooth Muscle
}

\begin{tabular}{|r|l|}
\hline Journal: & Neurourology and Urodynamics \\
\hline Manuscript ID: & NAU-11-0239.R1 \\
\hline Wiley - Manuscript type: & Original Basic Science Article \\
\hline Subject Sections: & $\begin{array}{l}\text { Neurourology: Basic science, Pharmacology: Basic science, Physiology: } \\
\text { smooth muscle }\end{array}$ \\
\hline Keywords: & urinary bladder, smooth muscle, action potentials, nitric oxide \\
\hline \multicolumn{2}{|l}{} \\
\hline
\end{tabular}

SCHOLARONE ${ }^{\mathrm{m}}$

Manuscripts 


\section{ABSTRACT}

Aims: We investigated the roles of neuronal-derived nitric oxide (NO) in the modulation of spontaneous activity of mouse detrusor smooth muscle. Methods: Detrusor smooth muscle strips were isolated from nNOS gene knock-out $\left(\mathrm{nNOS}^{-/-}\right)$mice and their wild type siblings $\left(\mathrm{nNOS}^{+/+}\right)$. The properties of smooth muscle cells were assessed using intracellular electrophysiology and $\mathrm{Ca}^{2+}$ imaging by laser-scanning confocal microscopy. The effects of an nNOS inhibitor, 7-nitro indazole (7-NI) on electrically-evoked contractility were assessed using $\mathrm{nNOS}^{+/+}$mouse detrusor strips. Results: In spontaneously active cells, the frequency of spontaneous action potentials (SAPs) and whole cell $\mathrm{Ca}^{2+}$ flashes in $\mathrm{nNOS}^{-/-}$preparations was lower than that in the $\mathrm{nNOS}^{+/+}$preparations. The frequency of SAPs was enhanced by a nitric oxide donor, diethylamine NONOate sodium salt (NONOate; $100 \mu \mathrm{M}$ ), both when used alone and when the cGMP pathway was blocked by $1 \mathrm{H}-[1,2,4]$ oxadiazolo [4, 3-a] quinoxalin-1-one (ODQ, $10 \mu \mathrm{M}) . \quad 7-\mathrm{NI} \quad(100 \mu \mathrm{M})$ significantly suppressed the electrically-evoked contraction of mouse detrusor strips. Conclusions: We suggest that neuronal-derived NO facilitates the generation of spontaneous activity via a cGMP-independent pathway, and consequently enhances the evoked contraction of detrusor. Dysregulation of nNOS containing nerves may underlie bladder pathologies. 


\section{INTRODUCTION}

Detrusor smooth muscle cells (SMCs) of the urinary bladder exhibit spontaneous contractile activity during the storage phase. This contractile activity is poorly synchronised between cells; thereby, maintaining the shape of the bladder without elevating intravesical pressure. ${ }^{1}$ It appears, however, that there may be alterations in contractile activity in certain bladder pathologies; overactive bladder, for example, is characterised by large amplitude, slow duration spontaneous contractions ${ }^{2}$ that may arise from increased synchronization of spontaneous activity of SMCs. ${ }^{3}$

Neural activation of the bladder has been shown to be mediated by several neurotransmitters, but principally by acetylcholine and ATP with species variations in the proportions of cholinergic and purinergic control. ${ }^{4-5}$ Another important neurotransmitter, nitric oxide (NO), may be released from motor fibres ${ }^{6}$, intramural ganglia ${ }^{7}$, urothelium $^{8}$, and from SMCs of the bladder. ${ }^{9}$ The application of NO donors reveals immunoreactivity for cyclic guanosine monophosphate (cGMP), a second messenger involved in NO signalling, in nerves, urothelium and interstitial cells of the bladder, but cGMP immunoreactivity was absent in detrusor smooth muscle ${ }^{10-11}$ suggesting any NO effect is likely to be cGMP-independent. The role NO signalling plays in the functioning of the bladder is far from clear, with conflicting studies demonstrating relaxation ${ }^{12}$ and enhancement of evoked contraction $^{11,13}$. Genetic disruption of neuronal-derived NO has been shown to evoke a dilated bladder and increased outflow resistance in male mice. ${ }^{14}$ Another study reported 


\author{
that there is no discernable cystometric effect in young female $\mathrm{nNOS}^{-/-}$mice. ${ }^{15}$ \\ In order to better understand the role of nNOS-derived NO on the spontaneous activity \\ of detrusor SMCs, we have studied spontaneous electrical activity and $\mathrm{Ca}^{2+}$ dynamics in \\ strips of detrusor dissected from the bladders of nNOS gene-disrupted mice and used \\ drugs which enhance or block NO.
}




\section{MATERIALS AND METHODS}

\section{General}

nNOS gene knock-out $\left(\mathrm{nNOS}^{-/-}\right)$mice and their wild type siblings $\left(\mathrm{nNOS}^{+/+}\right)$were obtained from a colony at the John Radcliffe Hospital (Oxford, UK) by backcrossing the nNOS ${ }^{-/-}$ (Jackson Laboratory, USA) on a C57BL/6 background. In order to confirm that the nNOS gene had been knocked out, mice were bred, chipped, and coded, and tail DNA samples were harvested for genotyping with polymerase chain reaction. ${ }^{16}$

Mice of either sex, weighing 20-39 g, were killed by head concussion followed by cervical dislocation. Efforts were made to minimise the number of animals used and their suffering; all experiments were carried out in accordance with the UK Animals (Scientific Procedures) Act 1986 and European Communities Council Directive 86/09/EEC and were approved by the Institutional Animal Care and Use Committee of the University of Oxford and National Defense Medical Center, Taipei, Taiwan pursuant to the Helsinki Declaration and internationally-accepted principles for the care and use of experimental animals. The urinary bladder was surgically removed and its ventral wall was opened longitudinally from the bladder neck to the top of the dome. The urothelium was either left intact (for microelectrode studies) or removed (for tension recording and $\mathrm{Ca}^{2+}$ imaging studies) by careful dissection (taking care not to stretch or damage the underlying detrusor muscle). Whole layer tissue strips, $6-8 \mathrm{~mm}$ long and 1-2 $\mathrm{mm}$ wide, which contained a few bundles of smooth muscle, were prepared as previously described. ${ }^{17}$ 


\section{Microelectrode recordings}

Following bridge-balancing to compensate for the tip resistance (200-300 M $\Omega$ ) of the microelectrode and neutralization of the tip capacitance, individual bladder smooth muscle cells in muscle bundles were impaled with microelectrodes from the serosal side. Membrane potential changes were recorded using a high input impedance amplifier (Axoclamp-2B; Axon Instruments, USA), and analysed as previously described. ${ }^{22}$

\section{$\mathrm{Ca}^{2+}$ imaging}

Detrusor muscle strips were exposed to $10 \mu \mathrm{M}$ Oregon Green 488 BAPTA-1 AM (Invitrogen, UK) in 1\% DMSO/0.2\% pluronic F-127 (Sigma, UK) in PSS for 70 min at $33{ }^{\circ} \mathrm{C}$. Each strip was then rinsed in PSS for 10 min before transfer to a chamber mounted on the stage of a confocal microscope and continuously superfused with standard PSS (bath temperature 35 $\left.{ }^{\circ} \mathrm{C}\right)$. Series of images were acquired and analysed as previously described. ${ }^{17}$

\section{Tension Recording}

Detrusor strips (approx. 5x1x1 mm; 2-4 mg) were tied at either end with suture (5/0; Pearsalls, UK) and mounted vertically in a $0.2 \mathrm{ml}$ capacity organ bath between two recessed platinum electrodes through which electrical field stimulation (EFS) was delivered. The strips were stretched with an initial force of $1 \mathrm{~g}$, and allowed to equilibrate for at least 1h prior to starting the experiments. The strips were constantly superfused with PSS $\left(37^{\circ} \mathrm{C}\right)$ at a rate of $1 \mathrm{ml} \cdot \mathrm{min}^{-1}$.

EFS was delivered from a stimulator (Grass S88; Grass Technologies, USA) at 
parameters of $0.05 \mathrm{~ms}$ pulse width, $3 \mathrm{~s}$ train duration, $50 \mathrm{~V}$ intensity, at varying frequency. Isometric tension generated by the strips was measured using isometric force displacement transducers (Dynamometer UFI; Pioden Controls Ltd, or AD Instruments MLT050/D), amplified and analyzed using PowerLab 4/30 (ADInstruments) and Chart software (v.7).

\section{Immunohistochemical study}

OCT $(0.1 \mathrm{ml})($ R.A. Lamb, UK) was injected into the lumen of a whole bladder through the urethra. Bladders were mounted in OCT and snap-frozen in isopentane-chilled liquid nitrogen. Cryosections $(10 \mu \mathrm{m})$ were cut and thaw-mounted onto glass slides pretreated with Vectabond reagent (Vector Laboratories, UK) and air-dried for 30-60 mins. Sections were fixed with acetone for 10 mins and then incubated overnight in a moisture chamber with a primary rabbit polyclonal antibody (NOS1[R20]; Santa Cruz, USA), diluted 1:50 with phosphate buffered saline (PBS; Oxoid Ltd, UK) and $0.5 \%$ bovine serum albumin (Sigma, UK). The next day, slides were washed three times with PBS and then incubated for 30 mins with secondary antibody (peroxidase conjugated swine anti-rabbit antibody; DAKO, UK) at a dilution of 1:50. After being washed, slides were incubated for another 30 mins with a tertiary antibody (peroxidase conjugated rabbit anti-swine antibody; DAKO, UK) at a dilution of 1:50. Slides were then washed again and incubated in substrate solution made with Sigmafast ${ }^{\mathrm{TM}}$-diaminodenzidine tablets (Sigma, UK) for 5 mins and then washed. Slides were then counterstained with filtered Harris's Hematoxylin (VWR International, UK) for 15 s, dehydrated with $100 \%$ alcohol, and treated with Histoclear (R.A. Lamb, UK). After 
mounting, slides were dried overnight. Micrographs were obtained by use of a digital camera (Coolpix 950; Nikon, Japan) attached to a microscope (DMRB; Leica, UK).

\section{Drugs and solutions}

To produce stock solutions, diethylamine NONOate sodium salt (NONOate) and 7-nitroindazole (7-NI; Sigma, UK) were dissolved in distilled water; $1 \mathrm{H}-[1,2,4]$ Oxadiazolo[4,3-a]quinoxalin-1-one (ODQ; Tocris, UK) was dissolved in dimethyl sulfoxide. Stock solutions were stored at $-20^{\circ} \mathrm{C}$. Drugs were delivered by substituting PSS with drug-containing solutions of the desired concentration for PSS. NONOate was stored in dark-coloured vessels in order to minimize light-induced degradation.

The PSS used had the following composition (mM): $\mathrm{NaCl}, 120 ; \mathrm{KCl}, 5.9 ; \mathrm{MgCl}_{2}, 1.2$; $\mathrm{CaCl}_{2} 2.5 ; \mathrm{NaHCO}_{3}, 15.5 ; \mathrm{NaH}_{2} \mathrm{PO}_{4}, 1.2$ and Glucose, $11.5 .^{17}$

\section{Analysis of data}

The normality and homogeneity of variance was tested prior to statistical analysis (Excel, Microsoft and Graph Pad Prism 5) using Kolmogorov-Smirnov and Levene's tests, respectively (SPSS v16; SPSS Inc., USA). Where data sets did not vary significantly from chance (i.e. $P>0.05$ ) for both tests, they are presented as mean \pm S.E.M. and the Student's $t$ test was used for comparison unless otherwise stated. In cases where data are non-parametric, the presentation method and statistical test are stated. The null hypothesis was rejected if $P<0.05$. The paired $t$ test or Wilcoxon signed rank test was used to compare pre- and post-treatment values of frequency and amplitude of sAPs generated 
from individual detrusor SMCs. The term $n_{\mathrm{a}}$ refers to the number of animals; $n_{\mathrm{smc}}$, number of smooth muscle cells; $n_{\mathrm{ap}}$, number of spontaneous action potentials. Square brackets are used to denote range. 


\section{RESULTS}

\section{Immunohistochemical identification of nNOS}

In order to validate the $\mathrm{nNOS}^{-/-}$strain, nNOS immunohistochemistry was performed. There was marked nNOS antibody staining of neurons in the suburothelial and detrusor layers of bladder wall and of nerve fibres traversing the detrusor layer in $\mathrm{nNOS}^{+/+}$mice $\left(n_{\mathrm{a}}=3\right)($ Fig. 1a). Large ganglia were most commonly found in the serosal layer (Fig. 1c). These structures were not stained in the bladder tissue from nNOS ${ }^{-/-}$mice (Fig. 1b,d).

\section{General electrical properties}

The resting membrane potentials (RMPs) of the urothelium intact detrusor SMCs, determined at the most negative potential between each action potential, was $-41 \mathrm{mV}$ in both $\mathrm{nNOS}^{-/-}$[range: -35 to $\left.-50 \mathrm{mV}\right]$ and $\mathrm{nNOS}^{+/+}[-34$ to $-59 \mathrm{mV}]$ preparations $\left(n_{\mathrm{a}}=11\right.$, $n_{\mathrm{smc}}=25$ and $n_{\mathrm{a}}=18, n_{\mathrm{smc}}=29$, respectively; $\left.P=0.9\right)$. The membrane potentials were interrupted by spontaneous action potentials (sAPs) and frequent spontaneous depolarizations (Fig.2a). Many of the properties of sAPs ${ }^{17}$ were no different between $\mathrm{nNOS}^{-/-}$and $\mathrm{nNOS}^{+/+}$preparations (Table 1). There was, however, a slower rate of decay in sAPs of $\mathrm{nNOS}^{-/-}$detrusor SMCs.

\section{The frequency of spontaneous action potentials was lower in $\mathrm{nNOS}^{-/-}$detrusor SMCs}

The frequency of sAPs recorded from the urothelium intact nNOS ${ }^{-/-}$detrusor SMCs $(2.3 \pm$ 
$0.38 \mathrm{~min}^{-1}, n_{\mathrm{a}}=13, n_{s m c}=25$ ) was significantly lower in comparison to those recorded from the intact nNOS ${ }^{+/+}$detrusor SMCs $\left(4.3 \pm 0.73 \mathrm{~min}^{-1} ; n_{\mathrm{a}}=19, n_{s m c}=29 ; P=0.025\right.$, Fig. $\left.2 \mathrm{~b}\right)$.

\section{Spontaneous $\mathrm{Ca}^{2+}$ dynamics of $\mathrm{nNOS}^{+/+}$and $\mathrm{nNOS}^{-/-}$detrusor SMCs}

The frequency of whole cell $\mathrm{Ca}^{2+}$ flashes in $\mathrm{nNOS}^{-/-}$preparations (median frequency: $0 \mathrm{~min}^{-1}$ range: $\left.[0,19], n_{\mathrm{a}}=7, n_{\mathrm{smc}=} 105\right)$ was lower than that in the $\mathrm{nNOS}^{+/+}$preparations $\left(1.1 \mathrm{~min}^{-1}[0\right.$, 58], $\left.n_{\mathrm{a}}=7, n_{\mathrm{smc}=} 152\right)(P<0.0001$, Mann-Whitney $U$ test; Fig. $2 \mathrm{c})$.

\section{Current-voltage relationship of mouse detrusor smooth muscle}

Input resistance was lower in $\mathrm{nNOS}^{-/-}$detrusor SMCs than in $\mathrm{nNOS}^{+/+}$preparations $(470 \pm$ $16 \mathrm{M} \Omega$ vs. $580 \pm 13 \mathrm{M} \Omega ; P<0.0001 ; n_{\mathrm{a}}=4, n_{\mathrm{smc}}=10$ for $\mathrm{nNOS}^{-/-} ; n_{\mathrm{a}}=5, n_{\mathrm{smc}}=12$ for $\mathrm{nNOS}^{+/+}$) (Fig. 3).

\section{Spontaneous depolarizations recorded from detrusor SMCs}

The frequency of spontaneous depolarizations (SDs) was no different in $\mathrm{nNOS}^{-/-}(8.7 \pm 1.6$ $\left.\min ^{-1}, n_{\mathrm{a}}=7, n_{\mathrm{smc}}=9\right)$ or $\mathrm{nNOS}^{+/+}$preparations (9.2 $\left.\pm 1.2 \mathrm{~min}^{-1}, n_{\mathrm{a}}=10, n_{\mathrm{smc}}=10\right)$ (Figure 4a). The shape of SDs did not differ (Table 1), but average SD amplitude was larger in $\mathrm{nNOS}^{-/-}$ detrusor SMCs (Figure 4b, c).

\section{Effect of a NO donor on $\mathrm{nNOS}^{+/+}$and $\mathrm{nNOS}^{-/-}$detrusor SMCs}

A nitric oxide donor NONOate was added to $\mathrm{nNOS}^{-/-}$preparations to determine whether the 
lower SAP frequency of detrusor SMCs in $\mathrm{nNOS}^{-/-}$could be restored to a frequency similar to $\mathrm{nNOS}^{+/+}$. NONOate $(100 \mu \mathrm{M})$ significantly increased the frequency of sAPs in $\mathrm{nNOS}^{-/-}$ preparations (from $1.9 \pm 0.7 \mathrm{~min}^{-1}$ to $9.4 \pm 3.3 \mathrm{~min}^{-1}, n_{\mathrm{a}}=8, n_{\mathrm{smc}}=10, P=0.048$, i.e. to a greater frequency than in $\mathrm{nNOS}^{+/+}$, which was $\left.4.3 \pm 0.73 \mathrm{~min}^{-1}\right)$. NONOate also reduced the amplitude of sAPs (from $54 \pm 2.1 \mathrm{mV}$ to $50 \pm 2.3 \mathrm{mV}, P=0.017$ ) and depolarised the resting potential (from $-44 \pm 1.6 \mathrm{mV}$ to $-38 \pm 2.6 \mathrm{mV}, P=0.015$ ).

\section{Effect of NO-sensitive guanylyl cyclase inhibition on $\mathrm{nNOS}^{+/+}$detrusor SMCs}

Soluble guanylyl cyclase is normally activated by NO to stimulate cGMP synthesis. A selective inhibitor of nitric oxide-sensitive guanylyl cyclase, ODQ, was added to $\mathrm{nNOS}^{+/+}$ preparations to block the synthesis of cGMP. ODQ $(10 \mu \mathrm{M})$ did not significantly affect the frequency (control: $1.6 \pm 0.7 \mathrm{~min}^{-1}$ vs. ODQ: $3.3 \pm 0.7 \mathrm{~min}^{-1}, P=0.09$ ) or amplitude (control: $56 \pm 0.5 \mathrm{mV}$ vs. ODQ: $55 \pm 0.3 \mathrm{mV}, P=0.29)$ of $\mathrm{sAPs}$ in $\mathrm{nNOS}^{+/+}$preparations $\left(n_{\mathrm{a}}=5\right.$ $\left.n_{\mathrm{smc}}=10\right)$. To determine whether NO affects spontaneous electrical activity in the absence of cGMP signalling, NONOate $(100 \mu \mathrm{M})$, added following incubation of the tissue (20 mins) with ODQ $(10 \mu \mathrm{M})$, increased SAP frequency from $3.3 \pm 0.7 \mathrm{~min}^{-1}$ to $8.6 \pm 1.9 \mathrm{~min}^{-1}\left(n_{\mathrm{a}}=4\right.$, $n_{\mathrm{smc}}=5, P=0.012$; Fig. 5). Adding ODQ subsequently did not affect the frequency of sAPs (NONOate + ODQ: $8.6 \pm 1.9 \mathrm{~min}^{-1}$ vs. NONOate: $6.3 \pm 2.4 \mathrm{~min}^{-1}, n_{\mathrm{a}}=4, n_{\mathrm{smc}}=5$ for NONOate + ODQ, $n_{\mathrm{a}}=6, n_{\mathrm{smc}}=6$ for NONOate, $\left.P=0.48\right)$. 


\section{Effect of nNOS inhibition on EFS-evoked contraction of detrusor}

In order to determine the effect of nNOS inhibition on EFS-evoked contractions, force-frequency relationships of $\mathrm{nNOS}^{+/+}$detrusor were compared in the presence and absence of the nNOS inhibitor 7-NI. 7-NI $(100 \mu \mathrm{M})$ significantly reduced the amplitude of EFS-evoked contractions at all frequencies (e.g. control amplitude at $20 \mathrm{~Hz}$ : $1.39 \pm$ 0.14 g.mg ${ }^{-1}$ vs. $7-\mathrm{NI}: 1.10 \pm 0.12$ g.mg $\left.^{-1} ; P<0.0001, n_{\mathrm{a}}=15\right)$ (Fig. 6a).

In order to determine whether there was an interaction between nNOS-derived NO and purinergic neurotransmission, force-frequency relationships were compared following purinoceptor desensitization by $\alpha, \beta$-methylene ATP $(\alpha, \beta$-mATP). $\alpha, \beta$-mATP (3 $\mu \mathrm{M})$ significantly reduced the force-frequency relationship (e.g. control amplitude at $20 \mathrm{~Hz}: 1.01$ \pm 0.16 g.mg ${ }^{-1}$ vs. $\alpha, \beta-\mathrm{mATP}: 0.49 \pm 0.07 \mathrm{~g} \cdot \mathrm{mg}^{-1}$; repeated measures ANOVA, $P<0.001, n_{\mathrm{a}}$ $=12)$. When detrusor strips were treated with $7-\mathrm{NI}(100 \mu \mathrm{M})$ in the presence of $\alpha, \beta-\mathrm{mATP}(3$ $\mu \mathrm{M})$, there was no additional reduction in the force-frequency relationship (e.g. $\alpha, \beta$-mATP at $20 \mathrm{~Hz}: 0.49 \pm 0.07$ g.mg ${ }^{-1}$ vs. $0.47 \pm 0.07$ g. mg $\left.{ }^{-1} ; P=\mathrm{NS}\right)$ (Fig. $\left.6 \mathrm{~b}\right)$. On a strip-by-strip basis, this was a mean reduction of $7 \pm 6 \%$ by $\alpha, \beta$-mATP $(3 \mu \mathrm{M})$ plus $7-\mathrm{NI}(100 \mu \mathrm{M})$ compared to the effect of $7-\mathrm{NI}(100 \mu \mathrm{M})$.

In order to determine whether there was an interaction between nNOS-derived NO and cholinergic neurotransmission, force frequency relationships were compared following muscarinic cholinergic receptor antagonism by atropine $(1 \mu \mathrm{M})$. Atropine $(1 \mu \mathrm{M})$ significantly reduced the force-frequency relationship (e.g. control amplitude at $20 \mathrm{~Hz}: 0.78$ 


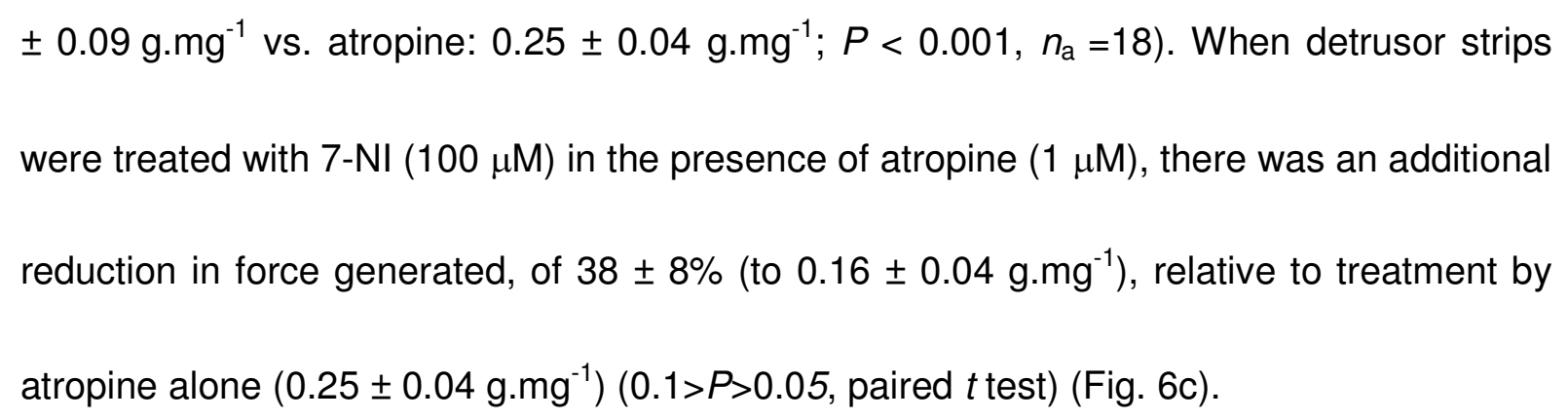




\section{DISCUSSION}

Spontaneous activity of the detrusor during the filling phase of the micturition cycle is of clinical relevance because bladder overactivity, a common and debilitating condition, is characterised by larger amplitude, fused spontaneous contractions of the detrusor. ${ }^{2}$ By comparing nNOS knock-out and sibling control mice we demonstrate that neuronal-derived NO plays an important role in generating and modulating the spontaneous activity of the detrusor.

\section{Confirmation of disruption of nNOS gene by lack of immunoreactivity}

Genetically-modified mice were used in the present study. The $\mathrm{nNOS}^{-/-}$strain used was originally developed by Huang et al. ${ }^{18}$, and has previously been used to investigate the role of NO in bladder function. ${ }^{14-15}$ Despite only the nNOS $\alpha$ splice variant being knocked-out in this $\mathrm{nNOS}^{-/-}$strain (i.e. meaning that the $\beta-, \gamma$ - and $\mu$-variants may still be present) neuronal nNOS containing neurons were absent (Figure 1), consistent with previous studies using the same strain of nNOS gene-disrupted mice ${ }^{14-15}$ and validating the use of this strain as a true $\mathrm{nNOS}^{-/-}$.

\section{nNOS derived NO enhances the spontaneous activity of the detrusor}

Detrusor SMCs generate SAPs caused by the opening of L-type $\mathrm{Ca}^{2+}$ channels and regulated by voltage-dependent mechanisms ${ }^{19}$. We used intracellular electrophysiology 
and confocal imaging to detect the spontaneous activity of detrusor SMCs. The frequency of these two measures of cellular activity was significantly lower in the $\mathrm{nNOS}^{-/-}$detrusor SMCs. After applying an NO donor (NONOate), the frequency of SAPs was augmented. This suggests that nNOS derived NO may play an excitatory role in the generation of sAPs and probably increase detrusor excitability; a finding that is consistent with previous research. $^{20}$

It has been demonstrated that NO, acting through S-nitrosylation pathways, acts as an excitatory agent in the regulation of electrical activity of excitable cells. ${ }^{21}$ Recently, Yoshida and colleagues ${ }^{22}$ presented a mechanism mediated by cysteine S-nitrosylation showing that NO may activate Transient Receptor Potential (TRP) channels and elicit entry of $\mathrm{Ca}^{2+}$ into human embryonic kidney cells, thereby causing excitation. Consistent with these studies, we demonstrated that NONOate enhanced the frequency of sAPs when the cGMP pathway was blocked by ODQ, suggesting NO may excite detrusor smooth muscle cells via a cGMP-independent pathway.

There were no significant differences in SAP waveform from $\mathrm{nNOS}^{-/-}$and $\mathrm{nNOS}^{+/+}$ detrusor apart from a small but significant difference in rate of decay. This change is similar to the change in the shape of sAPs after applying a $\mathrm{Ca}^{2+}$-activated $\mathrm{K}^{+}$channel blocker, charybdotoxin in guinea pig bladder $\mathrm{SMCs}^{19}$, suggesting that the lack of $\mathrm{NO}$ in $\mathrm{nNOS}^{-1-}$ mice may result in reduced function of the $\mathrm{Ca}^{2+}$-activated $\mathrm{K}^{+}$channels ${ }^{23}$ and/or $\mathrm{Ca}^{2+}$-mediated inactivation of the $\mathrm{Ca}^{2+}$ channels ${ }^{19}$, and consequently reduced the 
frequency of SAPs.

Input resistance is negatively correlated with the degree of electrical connectivity of SMCs local to the site of impalement. ${ }^{24}$ SMCs of $\mathrm{nNOS}^{-/-}$preparations exhibited lower input resistance compared to $\mathrm{nNOS}^{+/+}$preparations, indicating a greater degree of electrical coupling of SMCs in $\mathrm{nNOS}^{-/-}$detrusor muscle. The functional implications are not currently clear; perhaps increased intercellular coupling helps generate additional voiding pressure.

In a previous study we demonstrated that SDs, or spontaneous excitatory junctional potentials, occur when the magnitude of the current influx through $\mathrm{P} 2 \mathrm{X} 1$ is insufficient to trigger a SAP. ${ }^{25}$ It follows that the observation that $\mathrm{nNOS}^{-/-}$detrusor SMCs exhibit higher amplitude SDs and less frequent SAPs in $\mathrm{nNOS}^{-/-}$compared to $\mathrm{nNOS}^{+/+}$suggests that the size of nerve-released ATP packets in $\mathrm{nNOS}^{-/-}$is reduced. NO and ATP have been recognized as co-transmitters in the non-adrenergic non-cholinergic nerves. ${ }^{26}$ Therefore, absence of neuronal-derived NO may possibly reduce the amount of ATP in synaptic vesicles, reducing SAP frequency and consequently suppress detrusor contraction. This theory is supported by our tension recording experiments, in which a nNOS inhibitor, 7-NI, suppressed EFS-evoked contraction. No additional reduction of detrusor contractility was observed when 7-NI was subsequently applied in the presence of blockers of purinergic or cholinergic neurotransmission, implying that neuronal-derived NO may modulate the evoked contractility of detrusor pre- rather than post-junctionally.

A previous study has found that there are only interstitial cells and nerve fibres in the 
mouse bladder wall respond to NO. ${ }^{27}$ Fujiwara and colleagues demonstrated that EFS and the NO donor SIN-1 failed to induce relaxation of pre-contracted mouse detrusor preparations. In addition, SIN-1 and sodium nitroprusside were found to increase cGMP levels in the bladder tissue, but this increase was not correlated to smooth muscle relaxation. ${ }^{11}$ Therefore it is unlikely that NO causes relaxation of mouse detrusor smooth muscle. $^{11,28}$ Our data are in line with these studies and further demonstrated that nerve-derived NO plays an excitatory role in modulating mouse detrusor activity.

\section{CONCLUSION}

The present study suggests that neuronal-derived NO facilitates the generation of spontaneous activity via a cGMP-independent pathway, and contributes to the evoked contractility of detrusor. 


\section{ACKNOWLEDGEMENTS}

The authors thank Prof. Barbara Casadei, University Department of Cardiovascular Medicine, Oxford, for the generous gift of the nNOS wild-type and knock-out mice, Mrs Lucia Cerundolo for the technical assistance with immunohistochemistry and Dr Rob Amos for the image analysis algorithm.

\section{FUNDING}

Supported by Tri-Service General Hospital (TSGH-C100-075) and the National Science

Council of ROC, Taipei, Taiwan (98-2314-B-016-020-MY3). JSY was funded by a Wellcome Trust project grant (069768) to Dr Tom Cunnane, University of Oxford, UK. 


\section{REFERENCES}

1. Brading A. Overactive bladder: why it occurs. Women's Health Medicine 2005;2:20-23.

2. Kinder RB, Mundy AR. Pathophysiology of idiopathic detrusor instability and detrusor hyper-reflexia. An in vitro study of human detrusor muscle. Br J Urol 1987;60:509-15.

3. Brading AF. A myogenic basis for the overactive bladder. Urology 1997;50:57-67; discussion 68-73.

4. Andersson KE, Arner A. Urinary bladder contraction and relaxation: physiology and pathophysiology. Physiol Rev 2004;84:935-86.

5. Ruggieri MR, Whitmore KE, Levin RM. Bladder purinergic receptors. J Urol 1990;144:176-81.

6. Persson K, Alm P, Johansson K, et al. Nitric oxide synthase in pig lower urinary tract: immunohistochemistry, NADPH diaphorase histochemistry and functional effects. $\mathrm{Br}$ J Pharmacol 1993;110:521-30.

7. Zhou Y, Ling EA. Colocalization of nitric oxide synthase and some neurotransmitters in the intramural ganglia of the guinea pig urinary bladder. J Comp Neurol 1998;394:496-505.

8. Birder LA, Apodaca G, De Groat WC, et al. Adrenergic- and capsaicin-evoked nitric oxide release from urothelium and afferent nerves in urinary bladder. Am J Physiol 1998;275:F226-9.

9. Fathian-Sabet B, Bloch W, Klotz T, et al. Localization of constitutive nitric oxide synthase isoforms and the nitric oxide target enzyme soluble guanylyl cyclase in the human bladder. J Urol 2001;165:1724-9.

10. Smet PJ, Jonavicius J, Marshall VR, et al. Distribution of nitric oxide synthase-immunoreactive nerves and identification of the cellular targets of nitric oxide in guinea-pig and human urinary bladder by cGMP immunohistochemistry. Neuroscience 1996;71:337-48.

11. Fujiwara M, Andersson K, Persson K. Nitric oxide-induced cGMP accumulation in the mouse bladder is not related to smooth muscle relaxation. Eur $\mathrm{J}$ Pharmacol 2000;401:241-50.

12. Chung BH, Choi SK, Chang KC. Effects of nitric oxide on detrusor relaxation. J Urol 1996;155:2090-3.

13. Liu SH, Lin-Shiau SY. Enhancement by nitric oxide of neurogenic contraction in the mouse urinary bladder. Naunyn Schmiedebergs Arch Pharmacol 1997;356:850-2.

14. Burnett AL, Calvin DC, Chamness SL, et al. Urinary bladder-urethral sphincter dysfunction in mice with targeted disruption of neuronal nitric oxide synthase models idiopathic voiding disorders in humans. Nat Med 1997;3:571-4.

15. Sutherland RS, Kogan BA, Piechota HJ, et al. Vesicourethral function in mice with genetic disruption of neuronal nitric oxide synthase. J Urol 1997;157:1109-16. 
16. Sears CE, Bryant SM, Ashley EA, et al. Cardiac neuronal nitric oxide synthase isoform regulates myocardial contraction and calcium handling. Circ Res 2003;92:e52-9.

17. Meng E, Young JS, Brading AF. Spontaneous activity of mouse detrusor smooth muscle and the effects of the urothelium. Neurourol Urodyn 2008;27:79-87.

18. Huang PL, Dawson TM, Bredt DS, et al. Targeted disruption of the neuronal nitric oxide synthase gene. Cell 1993;75:1273-86.

19. Hashitani $\mathrm{H}$, Brading AF. Ionic basis for the regulation of spontaneous excitation in detrusor smooth muscle cells of the guinea-pig urinary bladder. $\mathrm{Br} \mathrm{J}$ Pharmacol 2003;140:159-69.

20. Yanai $\mathrm{Y}$, Hashitani $\mathrm{H}$, Hayase $\mathrm{M}$, et al. Role of nitric oxide/cyclic GMP pathway in regulating spontaneous excitations in detrusor smooth muscle of the guinea-pig bladder. Neurourol Urodyn 2008;27:446-53.

21. Ahern GP, Klyachko VA, Jackson MB. cGMP and S-nitrosylation: two routes for modulation of neuronal excitability by NO. Trends Neurosci 2002;25:510-7.

22. Yoshida T, Inoue R, Morii T, et al. Nitric oxide activates TRP channels by cysteine S-nitrosylation. Nature chemical biology 2006;2:596-607.

23. Mistry DK, Garland CJ. Nitric oxide (NO)-induced activation of large conductance Ca2+-dependent $\mathrm{K}+$ channels $(\mathrm{BK}(\mathrm{Ca}))$ in smooth muscle cells isolated from the rat mesenteric artery. Br J Pharmacol 1998;124:1131-40.

24. Purves RD. Current flow and potential in a three-dimensional syncytium. Journal of theoretical biology 1976;60:147-62.

25. Young JS, Meng E, Cunnane TC, et al. Spontaneous purinergic neurotransmission in the mouse urinary bladder. J Physiol 2008;586:5743-55.

26. Burnstock $\mathrm{G}$. The journey to establish purinergic signalling in the gut. Neurogastroenterol Motil 2008;20 Suppl 1:8-19.

27. Lagou M, Drake MJ, Markerink-Van Ittersum M, et al. Interstitial cells and phasic activity in the isolated mouse bladder. BJU Int 2006;98:643-50.

28. Persson K, Pandita RK, Aszodi A, et al. Functional characteristics of urinary tract smooth muscles in mice lacking cGMP protein kinase type I. Am J Physiol Regul Integr Comp Physiol 2000;279:R1112-20. 
Table 1. Descriptive statistics of the properties of SAPs and SDs recorded from $\mathrm{nNOS}^{+/+}$ and $\mathrm{nNOS}^{-1}$ detrusor SMCs.

\begin{tabular}{|c|c|c|c|}
\hline & $n N O S^{+/+}$ & $n N O S^{-/-}$ & Significance $(P)$ \\
\hline \multicolumn{4}{|l|}{ Shape ${ }^{17}$} \\
\hline Spike-type (\%) & 26 & 20 & 0.4 \\
\hline Pacemaker-type (\%) & 74 & 80 & \\
\hline \multicolumn{4}{|l|}{$s A P s$} \\
\hline Amplitude (mV) & $54 \pm 1.0$ & $53 \pm 1.0$ & 0.5 \\
\hline Half-width (ms) & $7 \pm 1.0$ & $8 \pm 0.3$ & 0.17 \\
\hline Rise time (ms) & $33 \pm 3.2$ & $38 \pm 3.4$ & 0.17 \\
\hline Rising slope (mV.ms $\left.{ }^{-1}\right)$ & $8.5 \pm 0.5$ & $7.3 \pm 0.4$ & 0.08 \\
\hline Rate of decay $\left(m V \cdot m s^{-1}\right)$ & $13 \pm 0.5$ & $11 \pm 0.6$ & 0.017 \\
\hline After-hyperpolarization amplitude ( $\mathrm{mV}$ ) & $9.1 \pm 0.7$ & $8.8 \pm 0.5$ & 0.69 \\
\hline$n_{a}$ & 19 & 13 & \\
\hline$n_{s m c}$ & 29 & 25 & \\
\hline \multicolumn{4}{|l|}{$S D s$} \\
\hline Amplitude (mV) & $6.2 \pm 0.5$ & $7.7 \pm 0.3$ & 0.016 \\
\hline Half-width (ms) & $51 \pm 5.7$ & $64 \pm 4.9$ & 0.13 \\
\hline Rise-time (ms) & $32 \pm 2.5$ & $29 \pm 19$ & 0.43 \\
\hline Time constant of decay (ms) & $46 \pm 5.2$ & $55 \pm 4.5$ & 0.22 \\
\hline$n_{s m c}$ & 10 & 9 & \\
\hline
\end{tabular}




\section{FIGURE LEGENDS}

Figure 1. nNOS immunoreactivity was absent in nNOS ${ }^{-/}$mouse bladder tissue. (a) nNOS positive ganglia (arrow) are seen in the serosal and detrusor layers in $\mathrm{nNOS}^{+/+}$, but (b) not in $\mathrm{nNOS}^{-/-}$bladder tissue. (c) At higher magnification nNOS positive staining of a ganglion (asterisk) and of nerve fibres (arrow head) was seen near the serosa of $\mathrm{nNOS}^{+/+}$ bladder, but (d) not in nNOS ${ }^{-/}$, but not in bladder tissue.

Figure 2. Spontaneous action potentials and whole cell $\mathrm{Ca}^{2+}$ flashes were less frequent in $\mathrm{nNOS}^{-/-}$that nNOS $^{+/+}$siblings. (a) Intracellular recordings from a $\mathrm{nNOS}^{+/+}$and a $\mathrm{nNOS}^{-/-} \mathrm{SMC}$. Resting membrane potentials were $-40 \mathrm{mV}$ for $\mathrm{nNOS}^{+/+}$and $-43 \mathrm{mV}$ for $\mathrm{nNOS}^{-/}$. (b) The frequency of SAPs in lower in SMCs from $\mathrm{nNOS}^{-1-}$ than nNOS ${ }^{+/+}$mice. The data shown are the mean and SEM. denotes $P<0.05\left(n_{\mathrm{a}}=18, n_{\mathrm{smc}}=29\right.$ for intact $\mathrm{nNOS}^{+/+} ; n_{\mathrm{a}}=11, n_{\mathrm{smc}}=25$ for intact $\mathrm{nNOS}^{-/}$). (c) The frequency of spontaneous whole cell flashes was greater in SMCs from nNOS ${ }^{+/+}$mice $\left(n_{\mathrm{a}}=7, n_{\mathrm{smc}}=152\right)$ than from $\mathrm{nNOS}^{-/-}$mice $\left(n_{\mathrm{a}}=5, n_{\mathrm{smc}}=105\right)$. There was, however, no significant difference in the whole cell flash amplitudes between the two groups $(\Delta \mathrm{F} / \mathrm{F}$ of 0.29 , $n_{\mathrm{smc}}=47$, in $\mathrm{nNOS}^{-/-}$preparations and $0.27, n_{\mathrm{smc}}=110$, in $\mathrm{nNOS}^{+/+}$preparations). Frequent $\mathrm{Ca}^{2+}$ waves and focal $\mathrm{Ca}^{2+}$ transients could also be seen within the individual smooth muscle cells, but their frequencies were not quantified as part of the present study. Data shown are frequencies and amplitudes per cell (symbols) and median per group (horizontal line). Statistical comparisons are Mann Whitney $U$ test.

Figure 3. $\mathrm{nNOS}^{-/-}$detrusor SMCs had a lower input resistance compared to $\mathrm{nNOS}^{+/+}$detrusor SMCs. The membrane properties of $\mathrm{nNOS}^{+/+}$and $\mathrm{nNOS}^{-/-}$mouse detrusor SMCs were examined by a series of brief 
intracellular current injections $(-0.1$ to $0.1 \mathrm{nA}$ for $100 \mathrm{~ms})$. The current-voltage relationship for SMCs in $\mathrm{nNOS}^{+/+}$and $\mathrm{nNOS}^{-/-}$was linear before the threshold of generating an action potential was reached (value of membrane potential: $0 \pm 2.2 \mathrm{mV}$ for $\mathrm{nNOS}^{+/+}$and $-10 \pm 2.2 \mathrm{mV}$ for $\mathrm{nNOS}^{-/}$). The input resistances of the detrusor SMCs calculated from a slope of the linear current-voltage relationship is significantly lower in $\mathrm{nNOS}^{-/}$preparations. The time constants of decay of the resultant electrotonic potential in SMCs were not significantly different $(7.9 \pm 0.9 \mathrm{~ms}$ vs. $7.6 \pm 0.7 \mathrm{~ms}, P=0.8)$. The fitted line above this threshold is a third-order polynomial. $\left(n_{\mathrm{a}=5}, n_{\mathrm{smc}}=12\right.$ for $\mathrm{nNOS}^{+/+} ; n_{\mathrm{a}}=4, n_{\mathrm{smc}}=10$ for $\left.\mathrm{nNOS}^{-/-}\right)$.

Figure 4. Larger amplitude spontaneous depolarizations (SDs) occurred more frequently in nNOS ${ }^{-/-}$ than $\mathrm{nNOS}^{+/+}$. (a) The frequency of SDs occurred in detrusor SMCs was no different in nNOS ${ }^{-/-}$mice $\left(n_{\mathrm{a}}=7\right.$, $\left.n_{\mathrm{smc}}=9\right)$ compared to that in $\mathrm{nNOS}^{+/+}$mice $\left(n_{\mathrm{a}}=10, n_{\mathrm{smc}}=10\right)(P=\mathrm{NS})$. (b) However, the amplitude distribution was shifted to the right in $\mathrm{nNOS}^{-/}$mouse detrusor SMCs, as demonstrated (c) by the corresponding significant difference in median amplitude between $\mathrm{nNOS}^{+/+}$and $\mathrm{nNOS}^{-/}$mouse detrusor SMCs.

Figure 5. NONOate enhanced the spontaneous activity of detrusor in the presence of a selective inhibitor of nitric oxide-sensitive guanylyl cyclase, ODQ $(10 \mu \mathrm{M})$, in the $\mathrm{nNOS}^{+/+}$mouse. (a) In the presence of ODQ, NONOate $(100 \mu \mathrm{M})$ significantly increased the frequency of SAPs (b) ODQ $(10 \mu \mathrm{M})$ alone did not increase sAP frequency in $\mathrm{nNOS}^{+/+}$detrusor SMCs $\left(n_{\mathrm{a}}=4\right)$. Statistical comparisons are one-way ANOVA followed by Tukey's multiple comparison test. ${ }^{* *}$ denotes $P<0.01{ }^{* * *}$ denotes $P<0.001$.

Figure 6. The nNOS inhibitor 7-NI reduced EFS-stimulated detrusor contracture but there was no additional reduction following purinergic desensitisation or cholinergic blockade. (a) $7-\mathrm{NI}(100 \mu \mathrm{M})$ suppressed the EFS evoked contraction of $\mathrm{nNOS}^{+/+}$detrusor smooth muscle strips $\left(n_{\mathrm{a}}=15\right)$. (b) P2X $\mathrm{X}_{1}$ receptor 


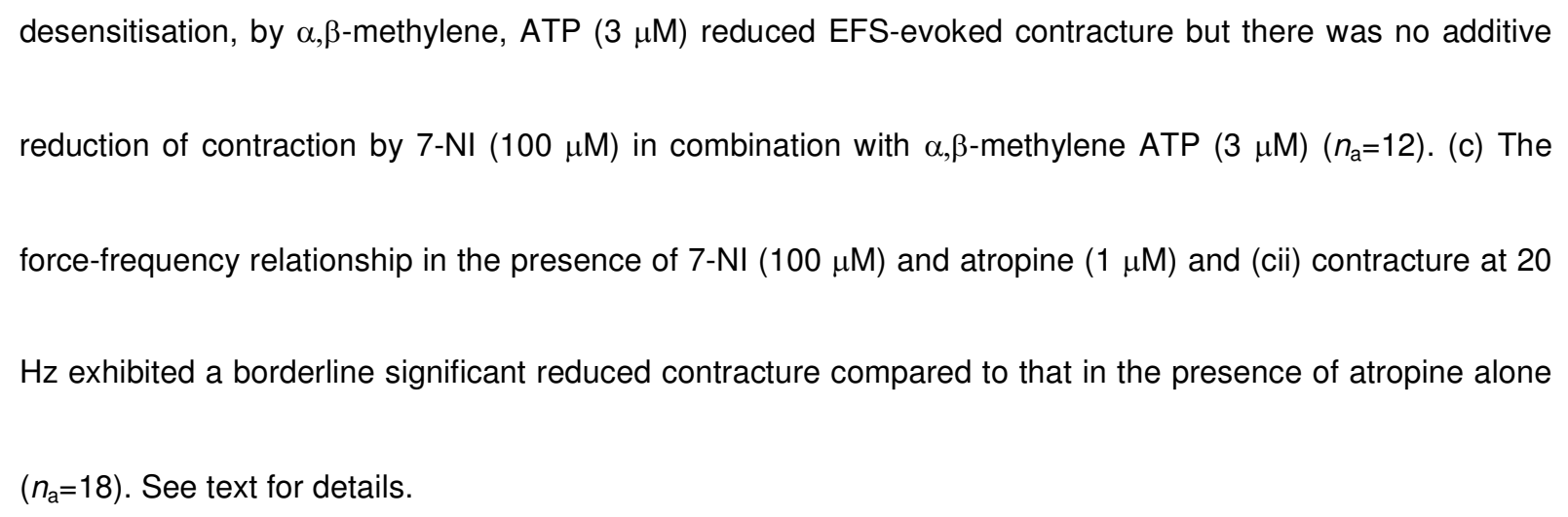





Figure 1. nNOS immunoreactivity is absent in nNOS-/- mouse bladder tissue. (a, nNOS positive ganglia (arrow) are seen in the serosal and detrusor layers in nNOS+/+, but not in nNOS-/- bladder tissue, (b). (c) At higher magnification nNOS positive staining of a ganglion (asterisk) and of nerve fibres (arrow head) was seen near the serosa of nNOS+/+ bladder, but not in nNOS-/- , but not in bladder tissue (d). $78 \times 69 \mathrm{~mm}(300 \times 300 \mathrm{DPI})$ 
$\mathrm{nNOS}^{+/+}$

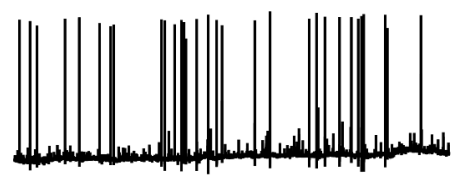

$\mathrm{nNOS}^{-/-}$
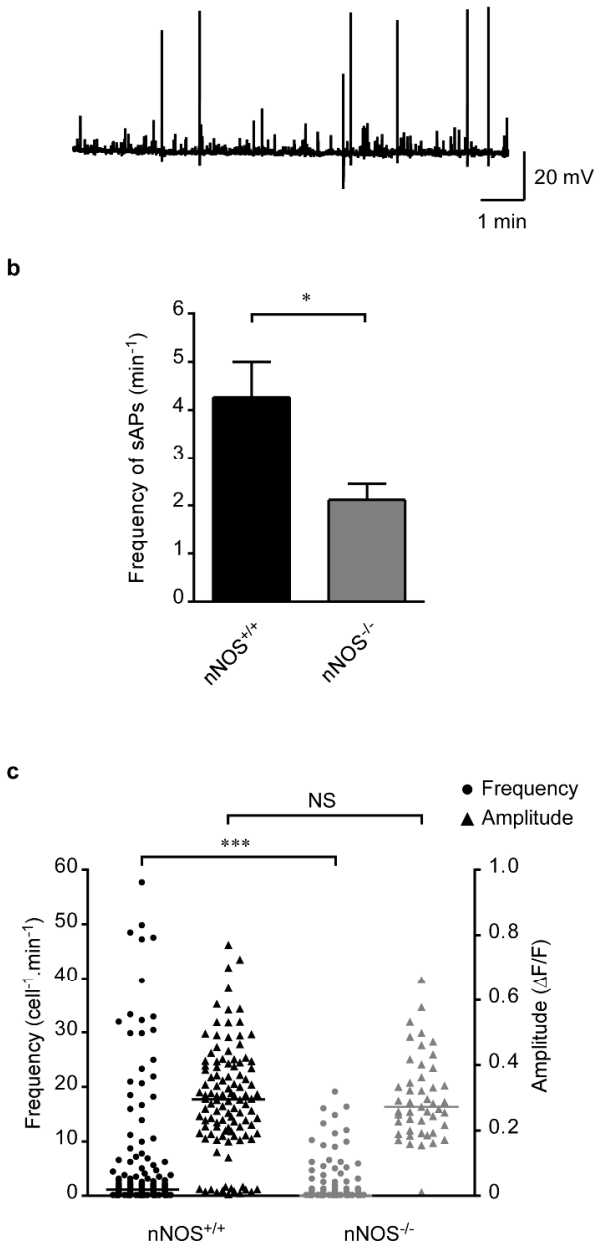

Figure 2. Spontaneous action potentials and whole cell Ca2+ flashes are less frequent in nNOS-/- that nNOS $+/+$ siblings. (a) Intracellular recordings from a nNOS $+/+$ and a nNOS-/- SMC. Resting membrane potentials were $-40 \mathrm{mV}$ for $\mathrm{nNOS}+/+$ and $-43 \mathrm{mV}$ for nNOS-/-. (b) The frequency of sAPs SMCs from nNOS/- mice was significantly lower compared to that from nNOS $+/+$ mice. The data shown are the mean and SEM. $*$ denotes $\mathrm{P}<0.05$ ( $\mathrm{na}=18, \mathrm{nsmc}=29$ for intact nNOS+/+; na $=11, \mathrm{nsmc}=25$ for intact nNOS-/-). (c)The frequency of spontaneous whole cell flashes was greater in SMCs from nNOS+/+ mice (na $=7$, nsmc $=152$ ) than from nNOS-/- mice. $* * *$ denotes $\mathrm{P}<0.001$ ( $\mathrm{na}=5$, nsmc $=105)$. There was, however, no difference in the whole cell flash amplitudes between nNOS $+/+(\mathrm{nsmc}=110)$ and nNOS-/- mice $(\mathrm{nsmc}=$ 47). Data shown are frequencies and amplitudes per cell (symbols) and median per group (horizontal line). Statistical comparisons are Mann Whitney $U$ test. $215 \times 574 \mathrm{~mm}(300 \times 300 \mathrm{DPI})$ 


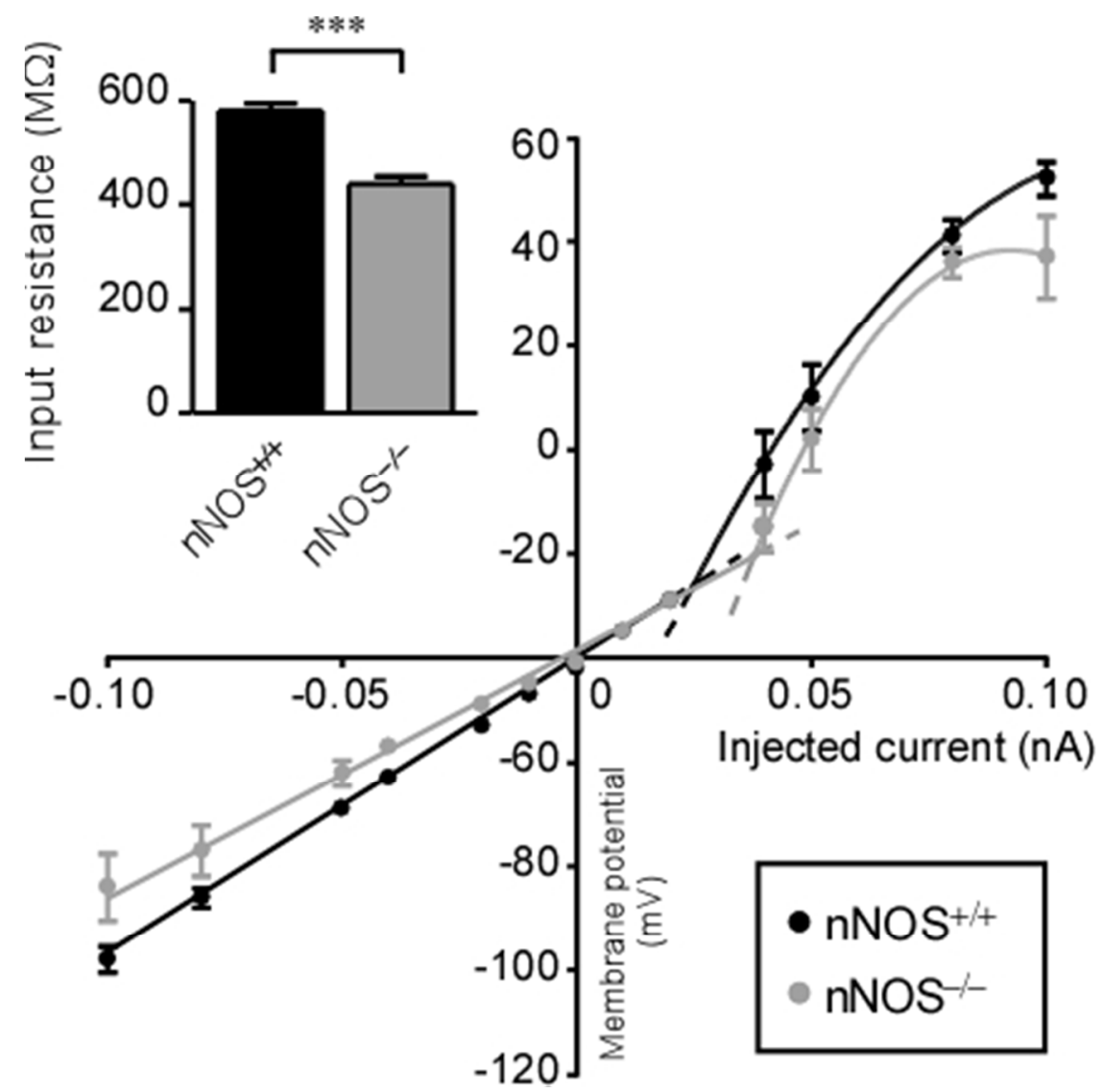

Figure 3. nNOS-/- detrusor SMCs have a lower input resistance compared to nNOS+/+ detrusor SMCs. The current-voltage relationship for SMCs in nNOS+/+ and nNOS-/- was linear before the threshold of generating an action potential was reached (value of membrane potential: $0 \pm 2.2 \mathrm{mV}$ for $\mathrm{nNOS}+/+$ and -10 $\pm 2.2 \mathrm{mV}$ for nNOS-/-). The input resistances of the detrusor SMCs calculated from a slope of the linear current-voltage relationship is significantly lower in nNOS-/- preparations. The fitted line above this threshold is a third-order polynomial. ( $\mathrm{na}=5, \mathrm{nsmc}=12$ for $\mathrm{nNOS}+/+$; na $=4$, nsmc $=10$ for $\mathrm{nNOS}-/-$ ). $72 \times 72 \mathrm{~mm}(150 \times 150 \mathrm{DPI})$ 
a

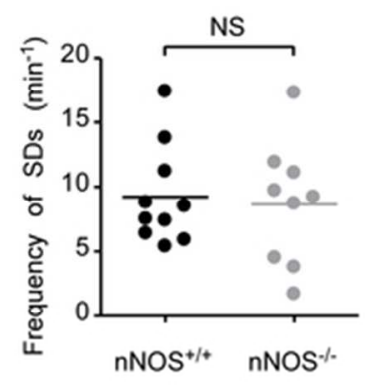

b

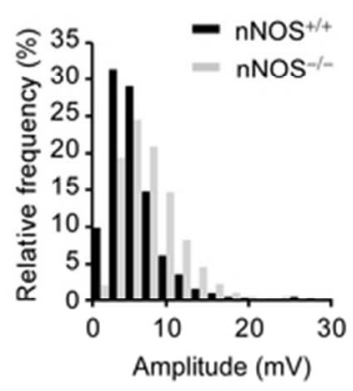

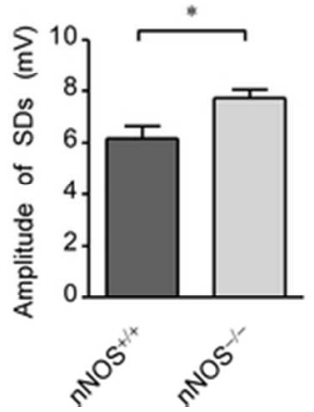

Figure 4. Larger amplitude spontaneous depolarizations (SDs) occurred more frequently in nNOS-/- than nNOS+/+. (a) The frequency of SDs occurred in detrusor SMCs was no different in nNOS-/- mice ( $\mathrm{na}=7$, $n s m c=9)$ compared to that in nNOS $+/+$ mice $(\mathrm{na}=10, \mathrm{nsmc}=10)(\mathrm{P}=\mathrm{NS})$. (b) However, the amplitude distribution was shifted to the right in nNOS-/- mouse detrusor SMCs, as demonstrated (c) by the corresponding significant difference in median amplitude between $\mathrm{nNOS}+/+$ and nNOS-/- mouse detrusor SMCs.

$54 \times 18 \mathrm{~mm}(300 \times 300$ DPI $)$ 
a

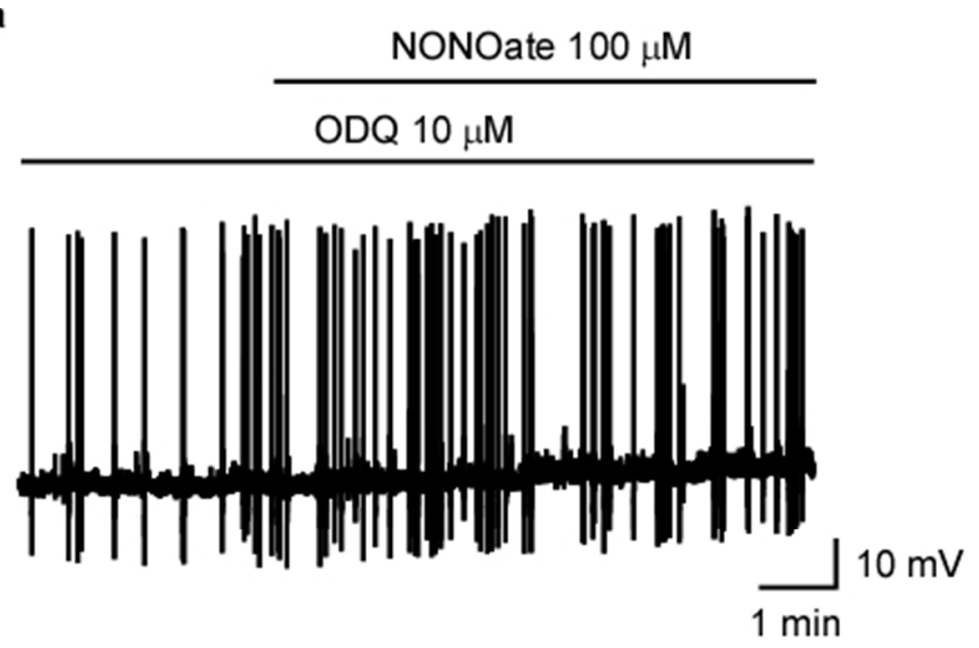

b

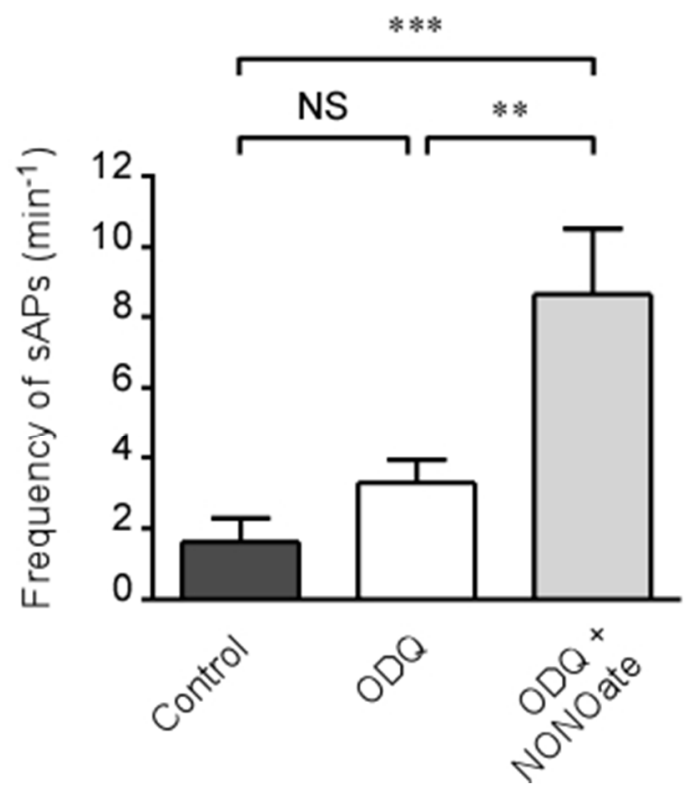

Figure 5. NONOate enhanced the spontaneous activity of detrusor in the presence of a selective inhibitor of nitric oxide-sensitive guanylyl cyclase, ODQ $(10 \mu \mathrm{M})$, in the nNOS+/+ mouse. (a) In the presence of ODQ, NONOate $(100 \mu \mathrm{M})$ significantly increased the frequency of sAPs (b) ODQ $(10 \mu \mathrm{M})$ alone did not increase sAP frequency in nNOS+/+ detrusor SMCs $(\mathrm{na}=4)$. Statistical comparisons are one-way ANOVA followed by Tukey's multiple comparison test. $* *$ denotes $\mathrm{P}<0.01, * * *$ denotes $\mathrm{P}<0.001$. $73 \times 117 \mathrm{~mm}(150 \times 150 \mathrm{DPI})$ 

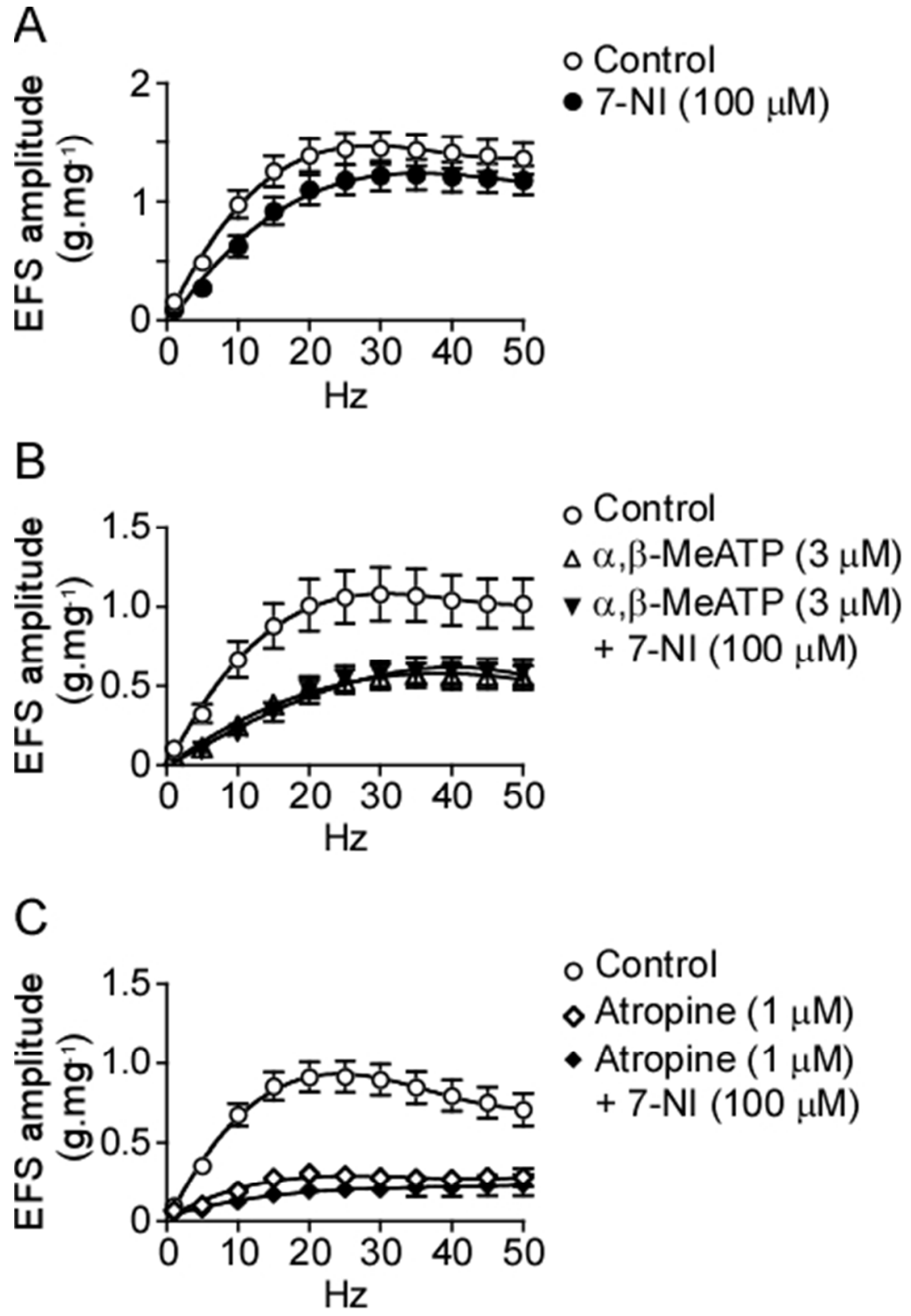

Figure 6. The nNOS inhibitor 7-NI reduced EFS-stimulated detrusor contracture but there was no additional reduction following purinergic desensitisation or cholinergic blockade. (a) 7-NI (100 $\mu \mathrm{M})$ suppressed the EFS evoked contraction of nNOS+/+ detrusor smooth muscle strips (na=15). (b) P2X1 receptor desensitisation, by a, $\beta$-methylene, ATP $(3 \mu \mathrm{M})$ reduced EFS-evoked contracture but there was no additive reduction of contraction by 7-NI $(100 \mu \mathrm{M})$ in combination with $a, \beta$-methylene ATP $(3 \mu \mathrm{M})(\mathrm{na}=12)$. (c) The forcefrequency relationship in the presence of 7-NI $(100 \mu \mathrm{M})$ and atropine $(1 \mu \mathrm{M})$ and (cii) contracture at $20 \mathrm{~Hz}$ exhibited a borderline significant reduced contracture compared to that in the presence of atropine alone $(\mathrm{na}=18)$. See text for details. $74 \times 109 \mathrm{~mm}(150 \times 150 \mathrm{DPI})$ 